to push the mucous film forward against its tendency to escape with the exhaled stream of water. Small particles and unicellular algæ have been found associated with the micro-gillrakers, although not in the quantities one might expect. The final collection and concentration of food is probably achieved by the pharyngeal apparatus 4 .

I have found micro-gillrakers in $T$. nigra. $T$. mossambica, T. esculenta, T. variabilis Blgr., T. zillii Gervais, and $T$. melanopleura. The shape of the microrakers and the teeth is identical in all these species, but in T. variabilis, $T$. zillii and T. melanopleura there are usually more teeth (10-16; Goose records 18 in T. melanopleura and T. nilotica). Adult T. zillii and $T$. melanopleura feed mainly on higher plants, but phytoplankton has been recorded as a subsidiary food in the latter ${ }^{3}$. Micro-rakers were not found in $T$. grahami, Blgr., a small species confined to the strongly alkaline waters of Lake Magadi, Kenya. They are however present in at least one species of Haplochromis, $H$. bloyeti (Sauvage) - again identical to those of $T$. nigra. In the cyprinid Labeo cylindricus Peters, an algal grazer, micro-rakers are absent. In this fish the gillrakers are very close set (about 60 on the lower part of the anterior arch) and probably provide a sufficiently fine filtration surface.

Micro-gillrakers may hold some systematic value (vide the greater numbers of teeth in certain species). They may however be of more importance at generic levels, particularly where specialization has been towards a piscivorous or molluscivorous habit. A rather simpler type of micro-raker is found in species of Citharinus (Characidæ), another filter feeder ${ }^{5}$.

Peter J. Whitehead

Ministry of Forest Development,

Game and Fisheries,

Nairobi, Kenya.

1 Fish, (G. R., Nature, 167, 900 (1951).

Vaas, K. H., and Hofstede, A. E., Contr. Int. Fish Res. St $t$. Bogor, 1 1 (1952).

Fish, G. R., Uganda J., 19 (1), 85 (1955).

Greenwood, P. H., Nature, 172, 207 (1953).

Gosse, J.-P., Soc. Roy. Zool. Belge, 86, 303 (1955).

\section{Infection of Cattle with Cysticercus bovis by the Injection of Onchospheres}

In 1907 Dévé $^{1}$ reported the successful infection of a rabbit by the subcutaneous injection of Echinococcus granulosus eggs which produced a single fertile hydatid cyst. Leonard and Leonard ${ }^{2}$, studying the resistance of rabbits to the larvæ of Tcenia pisiformis, infected these animals by the injection of hatched eggs into the mesenteric vein. Fedeli Avanzi ${ }^{3}$ reported that the intraperitoneal injection of hydatid sand into rabbits failed to produce any infection, but Batham ${ }^{4}$ success. fully infected mice by the intraperitoneal injection of E. granulosus eggs.

In the annual report of the Kenya Veterinary Department for $1944^{5}$ Mann is reported as having hatched $T$. saginata eggs in acid pepsin and pan. creatin solutions, but the onchospheres failed to infect calves when injected intravenously or subcutaneously.

It has been found by Froyd ${ }^{6}$ that adult cattle in Kenya are apparently resistant to infection with $T$. saginata eggs when these are given per os. A similar experience has been reported by Urquhart? In order to discover whether adults were totally resistant to infection, parenteral routes were tried, since work on other parasites had shown that there is probably more than one phase of resistance to parasitic infection ${ }^{2,8,8}$.

\begin{tabular}{|c|c|c|c|}
\hline $\begin{array}{r}\text { Table } 1 . \quad \text { RESULTS } 0 \\
\text { ONCHOSI }\end{array}$ & $\begin{array}{l}\text { INJECTYO } \\
\text { GRES IN }\end{array}$ & $\begin{array}{l}\text { F HATCHED } \\
\text { LT OATTLLE }\end{array}$ & . saginata \\
\hline & Artificia & Infection & Result \\
\hline Howe or hinection & Successful & Unsuccessful & \\
\hline $\begin{array}{l}\text { Naturally preinfected } \\
\text { cattle }\end{array}$ & & & \\
\hline Intravenous & 0 & 2 & - \\
\hline Subcutaneous & 1 & $\overline{2}$ & - \\
\hline $\begin{array}{l}\text { Subcutaneous and } \\
\text { intramuscular }\end{array}$ & 3 & 2 & 一 \\
\hline $\begin{array}{l}\text { Cattle not preinfected } \\
\text { intravenous }\end{array}$ & 0 & 0 & 2. of which \\
\hline & 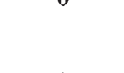 & & $\begin{array}{l}1 \text { died } 11 \\
\text { days after } \\
\text { injection }\end{array}$ \\
\hline $\begin{array}{l}\text { Subcutaneous } \\
\text { Subcutaneous and }\end{array}$ & 1 & 1 & $\ldots$ \\
\hline Total intramuscular & 5 & 5 & - \\
\hline Total & 10 & 12 & 2 \\
\hline
\end{tabular}

To date, 24 adult cattle have been injected intravenously, subcutaneously and/or intramuscularly with onchospheres of $T$. saginata, hatched by Silverman's technique ${ }^{10}$. Some of these beasts were found to be naturally preinfected by $C$. bovis.

The results of these injections are shown in Table 1.

Thus in ten animals cysts were found at the injection sites. One other, doubtful, beast injected intravenously had two small cysts in the intramuscular fascia of a hindleg, but their histological appearance was not sufficiently conclusive to allow a definite diagnosis of $C$. bovis infection.

In two cases viable cysts were demonstrated at the injection site. In several others macroscopical evidence of cysts was noted, proved histologically to be indistinguishable from cestode tissues and in some cases showing scolices, thus leading to a definite diagnosis of successful parenteral infection.

Batches of eggs vary in the viability of the onchospheres which they produce. Seven of the negative cases above belonged to one batch which, though infective for calves, failed to infect any adult bovine. Excluding that group our series gave 58.8 per cent infection instead of 41.7 per cent all inclusive.

A fuller report on the above experiments will be published elsewhere.

This letter is published with the permission of the Director of Veterinary Services, Kenya.

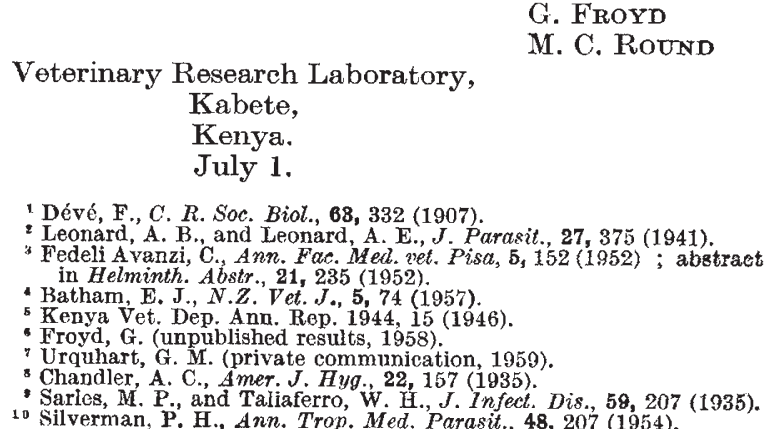

Veterinary Research Laboratory,

Kabete,

Kenya.

July 1.

'Dévé, F., C. R. Soc. Biol., 68, 332 (1907).

" Leonard, A. B., and Leonard, A. E., J. Parasit., 27, 375 (1941).

Fedeli Avanzi, C., Ann. Fac. Med. vet. Pisa, $5,152(1952)$; abstract in Helminth. Abstr., 21, 235 (1952).

s Batham, E. J., N.Z. Vet. J., 5, 74 (1957).

- Kenya Vet. Dep. Ann. Rep. 1944, 15 (1946)

Froyd, G. (unpublished results, 1958)

- Urquhart, G. M. (private communication, 1959)

- Chandes, M. A. C., Amer. J. Hyg 22 2, 157 (1935)

10 Saries, M. P., and Taliaferro, W. H., J. Infect. Dis., 58, 207 (1935).

\section{Conjugation in Spirostomum}

ANY report of conjugation in Spirostomum is of special interest because of its extreme rarity. To our knowledge the last report was by Bishop ${ }^{3}$ nearly thirty-six years ago in $S$. ambiguum. Earlier, Stein ${ }^{1}$ and Balbiani ${ }^{2}$ had observed the process in the same species. In no case was it noticed as a regular phenomenon (as in Paramecium and other ciliates) affecting considerable numbers of animals in a population. Nor were any of these authors able to present a full account of the conjugation process, since it was encountered by them very infrequently. As Bishop says, "There 